Çukurova Üniversitesi Mühendislik Mimarlık Fakültesi Dergisi, 29(2), 39-53 ss., Aralık 2014

Çukurova University Journal of the Faculty of Engineering and Architecture, 29(2), pp. 39-53, December 2014

\title{
Ön Konsolidasyon Basıncı
}

\author{
Hüseyin YILDIRIM*1 ${ }^{*}$ Ayşen ÇELEBí ${ }^{1}$ \\ ${ }^{1}$ İstanbul Teknik Üniversitesi, İnşaat Fakültesi, İnşaat Mühendisliği Bölümü, İstanbul \\ Geliş tarihi: 23.07.2014 Kabul tarihi: 25.12.2014
}

\section{Özet}

Çalışmada yeniden konsolide edilerek hazırlanan 9 farklı numune ve 2 örselenmemiş numune ile yeterli sayılarda bir boyutlu ve üç boyutlu konsolidasyon deneyleri yapılarak deney yönteminin ve numune tipinin ön konsolidasyon basıncına etkisi araştırılmıştır. Gerek bir boyutlu gerekse üç boyutlu deney aletleri kullanılarak yapılan bir boyutlu konsolidasyon deneyi sonuçları $\operatorname{Ln}(1+\mathrm{e})$-Logaritma düşey gerilme eksenlerinde çizilmiştir. İlgili eksenlerde oturma eğrilerinin iki doğrudan oluştuğu bulunmuştur. Hem bir, hem de üç boyutlu deney aleti ile yapılan bir boyutlu deney sonuçlarında ön konsolidasyon basınçları Ln(1+e)-Logaritma düşey gerilme yöntemine göre yaklaşı aynı bulunmuştur. Üç boyutlu deney aleti ile yapılan bir boyutlu ve üç boyutlu deney sonuçlarında ön konsolidasyon basınçları Casagrande yöntemi ile belirlenmiştir. Casagrande yöntemine göre bir boyutlu deney sonuçlarında bulunan ön konsolidasyon basınçları, üç boyutlu konsolidasyon deneylerinden bulunan değerlerinden daha küçüktür. Hesaplama yönteminin ön konsolidasyon basıncına etkisinin araştırılması amacıyla bir ve üç boyutlu deney sonuçlarında ön konsolidasyon basınçları Sıkışma modülü-Logaritma düşey gerilme yöntemine göre de hesaplanmıştır.

Anahtar Kelimeler: Ön konsolidasyon basıncı, Farklı deney yöntemleri, Farklı hesap yöntemleri

\section{Preconsolidation Pressure}

\begin{abstract}
By performing sufficient numbers of one and three-dimensional consolidation tests, on 9 different reconstituted samples and 2 undisturbed specimens, the effects of sample and test type on preconsolidation stress have been investigated in the study. One dimensional consolidation test results, carried out using either one or three dimensional test devices, have been plotted at $\operatorname{Ln}(1+\mathrm{e})-\log$. vertical stress axes. Settlement curves have been found to become two straight lines at the corresponding axes. The preconsolidation pressures, on the one dimensional results, performed by using both one and three dimensional test devices, are approximately the same according to $\operatorname{Ln}(1+\mathrm{e})$-Log. vertical stress method. The preconsolidation pressures, on the one and three dimensional test results, carried out with three dimensional test apparatus, have been determined according to the Casagrande procedure. The preconsolidation pressures, on the one dimensional test results, are smaller than the corresponding values, determined from three dimensional test results, depends on the Casagrande construction. By the purpose
\end{abstract}

\footnotetext{
* Yazışmaların yapılacağı yazar: Hüseyin YILDIRIM, I.T.Ü., Inşaat Fakültesi, İnşaat Mühendisliği Bölümü, İstanbul, aysen.aysen06@mynet.com
} 
of examining the effect of the method used on the preconsolidation pressure, the preconsolidation pressures, on the one and three dimensional test results, have also been determined with Compression modulus - Log. vertical stress construction.

Keywords: Preconsolidation pressure, Different test methods, Different identifing methods

\section{GİRİŞ}

Ön konsolidasyon basıncının gerçek değerine yakın belirlenebilmesi, konsolidasyon oturmasının hesaplanmasında önemlidir. Bazı araştırmacılar tarafından yeniden konsolide edilerek hazırlanan numunelerde akma gerilmesi olarak da isimlendirilen ön konsolidasyon basıncını, numunelerin örselenmesi, farklı deney yöntemleri, gerilme artım oranı, gerilmelerin bulunma süresi ve farklı hesap yöntemlerinin etkilediği bilinmektedir. Numunelerin araziden alınmaları, laboratuara taşınmaları, laboratuarda deneyler için hazırlanmaları aşamalarında yeterli önem gösterilmesine rağmen bazı örselenmeler oluşmaktadır. $\mathrm{Bu}$ örselenmeler Casagrande yöntemine dayalı ön konsolidasyon basıncının belirlenmesi aşamasında oturma grafiğinde eğriliğin en küçük olduğu noktanın belirlenmesini güçleştirecektir. Dolayısıyla bu yöntem ile belirlenen ön konsolidasyon basıncı gerçek değerine uygun olmayacaktır. Brumund vd. [1] çalışmasına dayalı olarak numunede örselenme miktarı arttıkça, ön konsolidasyon basıncı, gerçek değerinden daha küçük olarak bulunmaktadır.

Ödometre deneylerinde gerilme artım oranı (LIR) genel olarak bir olacak biçimde uygulanmaktadır. Numunelerde bulunan örselenmelerin, oturma eğrilerine etkileri, Leonard [2], Holtz ve Kovacs [3] ve Sandbaeken vd. [4] çalışmalarında önerildiği üzere, ön konsolidasyon basınc1 değerine yaklaşıldığında gerilme artım oranının küçültülmesi ile giderilmektedir. Gerilme artım oranı küçültülerek oturma grafiklerinin yeniden yükleme bölümünden eğrilerin doğru olan bölümlerine geçiş daha iyi tanımlanabilmektedir. Gerilme artım oranının değiştirilmesinin de konsolidasyon katsayısı hesabında sorun olabileceğine inanılmaktadır. $\mathrm{Bu}$ çalışmada bir boyutlu ve üç boyutlu konsolidasyon deneyi sonuçlarına bağımlı çizilen oturma grafiklerinde, ön konsolidasyon basincı belirlenerek deney yönteminin ön konsolidasyon basıncına etkisi araştırılmıştır. Benzer çalışma örselenmemiş blok numuneler ile laboratuarda yeniden konsolide edilerek hazırlanan numuneler kullanılarak Nash vd. [5] yayınında yapılmıştır. Nash vd. [5] yayınında standart gerilme artım yöntemi (IL), sabit deformasyon oranında (CRS), ve akımın engellendiği (RF) olmak üzere üç grup deney yapılarak deney yönteminin ön konsolidasyon basıncına etkisi araştırılmıştır. Sabit deformasyon oranında (CRS) yapılan deney sonuçlarından diğerlerine oranla daha büyük değer ön konsolidasyon basınc1 olarak bulunmuştur. Gözlenen deneysel sonucun da deformasyon hızına bağımlı olduğu ayrıca aynı derinlikten alınan numunelerden benzer sonuçların bulunması dikkate alınarak deney yönteminin ön konsolidasyon basıncına etkisinin olmadığı ilgili çalışmada belirtilmiştir.

Konu ile ilgili diğer bir çalışma örselenmemiş blok ve piston yöntemi kullanılarak alınan numuneler ile Holtz vd. [6] yayınında yapılmıştır. Holtz vd. [6] çalışmasında da standart gerilme artım yöntemi (IL), sabit deformasyon oranı (CRS) ve hidrolik eğim kontrollü (CHG) deneyler yapılarak deney yöntemi ile numune alma yönteminin ön konsolidasyon basıncına etkisi araştırılmıştır. İlgili yayında yapılan deneylerde, piston yöntemi ile alınan örselenmemiş numunelerden bulunan ön konsolidasyon basıncinın blok numunelerden belirlenen değerinden az bir miktar küçük olduğu bulunmuştur. Holtz vd. [6] yayınında gerilme artım oranı ön konsolidasyon basıncı değerine yaklaşıldığında azaltılarak oturma grafikleri iyileştirilmiştir. Konu edilen çalışmada ön konsolidasyon basıç̧ları Casagrande yöntemine göre hesaplanmıştır. Yazarlara göre ön 
konsolidasyon basıncına numune alma yönteminin yanı sıra deney yönteminin de etkisi bulunmaktadır. Deneysel çalışmadan en büyük ön konsolidasyon basinc1 sabit deformasyon uygulanan (CRS) deney sonuçlarından bulunmuştur. $\mathrm{Bu}$ değeri hidrolik eğim kontrollü (CHG) deney sonuçlarından belirlenen ön konsolidasyon basıncı değeri izlemektedir. En küçük değer ise standart gerilme artımının uygulandığı (IL) deney grubundan bulunmuştur. Ancak yazarlar tarafindan sabit deformasyon uygulanan (CRS), ve hidrolik eğimin kontrol edildiği (CHG) deney sonuçlarından bulunan ön konsolidasyon basıncı değerlerinin yükleme hızına bağımlı olduğu ve yükleme hızı arttıkça ilgili değerin arttığı sonucu açıklanmaktadır.

Ön konsolidasyon basıncının belirlenebilmesinde Casagrande yönteminin yanı sıra dört farklı yöntemin kullanımı da önerilmektedir. Numunelerde örselenmelerin bulunduğu durumlarda deney sonuçları Ln $(1+e)$ ve logaritma düşey efektif gerilme eksenlerinde çizildiğinde oturma eğrilerinin iki doğrudan oluştuğu Butterfield [7], Onitsuka vd. [8] ve Hong vd. [9] yayınlarında gösterilmektedir. İlgili çalışmalarda iki doğrunun kesim noktası ön konsolidasyon basınc1 olarak tanımlanmaktadır. Buradaki çalışmada da hem üç boyutlu deney aleti hem de ödometre deney aleti ile yapılan bir boyutlu deney sonuçları bu biçimde değerlendirilerek, 9 ayrı numune sonucuna dayalı çizilen oturma eğrilerinin iki doğrudan oluştuğu görülmüştür. Nash vd. [5] çalışmasında üç ayrı deney grubundan belirledikleri deney sonuçlarını bu yöntemi kullanarak değerlendirmişlerdir. $\mathrm{Bu}$ biçimde hesapladıkları ön konsolidasyon basınc1 değerlerinin Casagrande yöntemi ile bulunan değerlerine benzer olduğu Nash vd. [5] çalışmada görülmüştür. Standart gerilme artımının (IL) uygulandığı deney sonuçlarından ilgili değer Casagrande yöntemine göre $64 \mathrm{kPa}, \operatorname{Ln}(1+\mathrm{e})$ ve Logaritma düşey efektif gerilme yöntemine göre $63 \mathrm{kPa}$ olarak bulunmuştur. İlgili çalışmada ön konsolidasyon basıncına yaklaşıldığında oturma eğrileri gerilme artım oranı küçültülerek iyileştirilmiştir. Ln (1+e)-Logaritma düşey gerilme yönteminin kullanımı oturma eğrisinin düzeltilmesine olanak sağlamamaktadır.
Ön konsolidasyon basıncının belirlenmesinde kullanılan diğer bir yöntem, sıkışma modülüne $\left(\mathrm{Mc}=1 / \mathrm{m}_{\mathrm{v}}\right)$ karşıllı, logaritma düşey efektif gerilme eksenlerinde deney sonuçlarının çizilmesidir $[5,10]$. Çizilen grafikte en küçük modül değerine karşılık gelen gerilme değeri ön konsolidasyon basıncı olarak tanımlanmaktadır. Bu çalışmada da hem bir boyutlu deney sonuçları hem de üç boyutlu deney sonuçları bu yönteme göre değerlendirilmiş ve farklı hesaplama yöntemlerinin ön konsolidasyon basıncına etkisi araştırılmıştır.

Schmertman düzeltmesi ve deformasyon enerjisi yöntemleri çalışmada kullanılmamıştır.

\section{NUMUNELERINN HAZIRLANMASI VE ENDEKS ÖZELLÍKLERİ}

Deneysel çalışmada kullanılan numuneler ilk olarak etüvde yeterli zaman süresince kurutulup, daha sonra dövülerek danelerine ayrılıp 40 numaralı elekten elenerek, elek altına geçen malzemeden yeterli miktar alınmıştır. Daha sonra likit limit değerlerinin yaklaşık iki katı su muhtevasında, havası alınan su ile iyice karıştırılarak laboratuarda yeniden konsolide edilerek hazırlanmıştır. Numune hazırlamakta kullanılan çamur konsolidasyon aletinin boyutları, çap1 d=19 cm, yüksekliği $\mathrm{h}=81 \quad \mathrm{~cm}$ 'dir. Numuneler çamur konsolidasyon aletine alınmadan, en az üç gün karışım kabında bekletilip, karıştırılarak danelerin tabana çökelmesine izin verilmemiştir. Böyle bir işlemden beklenen, homojen ve tamamen suya doygun karışımın temin edilebilmesidir. Daha sonra çamur konsolidasyon aletine alınıp eksenel olarak gerilme uygulanmasına izin veren askı ve piston yardımı ile (pistonun ağırlığ 9270 g, kolun ağırlığ 9600 g) yaklaşık $125 \mathrm{kPa}$ basınç kademesinde konsolide edilmişlerdir. Sözü edilen basınç kademesine, olası numune kaybını önlemek amacı ile ortalama beş veya altı kademede ulaşılmaktadır. Yaklaşık en az üç ay eksenel basınç altında konsolide edildikten sonra, bu aletten alınarak, üç boyutlu konsolidasyon ve ödometre deneylerinin yapımında kullanılmışlardır. Çamur konsolidasyon aletinin alt ve üst başlıklarında bulunan geçirimli 
taşlar, konsolidasyon esnasında her iki yönden drenaja olanak sağlamaktadır.

Yukarıda açıklanan işlemden önce, çalışmada kullanılan her numune ile yeterli sayılarda hidrometre deneyi, likit limit, plastik limit ve piknometre deneyleri yapılıp, numuneler birleşik zemin sinıflandırma yöntemine göre sınıflandırılmıştır. Numunelerin endeks özellikleri Çizelge 1'de özetlenmiştir.

Laboratuarda yeniden konsolide edilerek hazırlanan zeminler arazideki gerçek zeminlerden pek çok özellik yönünden farklılık göstermektedir. Arazideki durum ile kıyaslandığında laboratuarda daha küçük eksenel gerilme ile konsolide edilmektedirler. Konsolidasyon gerilmesinin küçük olması dolayısıyla daneler arası bağ kuvvetleri küçüktür. Daneler arası yüzey kuvvetleri ile oluşan zemin dokusu ve buna bağımlı olarak oluşan zemin yapısı laboratuarda hazırlanan numunelerde bulunmamaktadır. Numuneler konsolide edildikten hemen sonra deney yapımında kullanılmaktadir. Laboratuarda konsolide edilerek hazırlanan numuneler ile belirlenen zemin özellikleri yalnızca danelerin yapısına bağımlıdır. Arazideki zeminin doku ve yapısını temsil etmemektedirler. Bu durum dikkate alınarak, çalışmada örselenmemiş örnekleri bulunan 4 ve 5 numaralı numuneler ile de standart ödometre deneyleri yapılarak oturma davranışları karşılaştırılmıştır. $\mathrm{Bu}$ numuneler kullanılarak yapılan deneylerde de diğer deney sonuçları ile karşılaştırılabilsin diye aynı numune çapı $(d=50$ $\mathrm{mm})$ ve aynı numune yüksekliği $(\mathrm{h}=20 \mathrm{~mm})$ kullanılmıştır.

\section{BİR BOYUTLU VE ÜÇ BOYUTLU KONSOLIDASYON DENEYLERI}

Farklı plastisite indisli 9 ince daneli numune kullanılarak çalışmada yeterli sayılarda üç boyutlu ve bir boyutlu konsolidasyon deneyleri yapılmıştır. Laboratuarda yeniden konsolide edilerek hazırlanan ve örselenmemiş numuneler kullanılarak yapılan bütün deney sayıları Çizelge 2'de gösterilmiştir. Üç boyutlu deney aleti Şekil 1'de görüldüğü üzere iki moment kolu yardımı ile numuneye eksenel gerilme uygulanmasına olanak sağlamaktadır. Moment kollarından biri $120 \mathrm{~mm}$ çapındaki numunenin merkez bölgesine Şekil 2'de gösterilen pistonlar yardımı ile eksenel gerilme uygularken diğeri merkez bölgenin çevresinde bulunan bölgeye gerilme uygulanmasında kullanılmaktadır. Deneyler esnasında hem çevre bölgeye hem de merkez bölgeye $(\mathrm{d}=50 \mathrm{~mm})$ aynı anda ilk olarak $100 \mathrm{kPa}$ eksenel basınç uygulanmaktadır.

Çizelge 1. Numunelerin endeks özellikleri

\begin{tabular}{|c|c|c|c|c|c|c|c|c|c|c|c|}
\hline $\begin{array}{c}\text { Zemin } \\
\text { No }\end{array}$ & $\mathrm{Wn}$ & $\mathrm{V}_{\mathrm{S}}$ & $\mathrm{W}_{\mathrm{L}}$ & $\mathrm{W}_{\mathrm{p}}$ & $\mathrm{I}_{\mathrm{p}}$ & $\mathrm{I}_{\mathrm{L}}$ & $\mathrm{I}_{\mathrm{c}}$ & $\begin{array}{c}\text { Ince } \\
\text { Kum }\end{array}$ & Silt & Kil & $\begin{array}{c}\text { Zemin } \\
\text { Grubu }\end{array}$ \\
\hline- & $(\%)$ & $\left(\mathrm{kN} / \mathrm{m}^{3}\right)$ & $(\%)$ & $(\%)$ & $(\%)$ & - & - & $(\%)$ & $(\%)$ & $(\%)$ & - \\
\hline N1 & 51,8 & 27,6 & 71,6 & 35,3 & 36,3 & 0,4 & 0,5 & 6,0 & 75,2 & 18,8 & $\mathrm{MH}$ \\
\hline N2 & 57,3 & 27,6 & 90,5 & 36,1 & 54,4 & 0,3 & 0,6 & 11,0 & 49,0 & 40,0 & CH \\
\hline N3 & 19,0 & 28,1 & 20,0 & 15,0 & 5,0 & 0,8 & 0,2 & 19,5 & 69,3 & 11,2 & CL-ML \\
\hline N4 & 27,2 & 27,5 & 31,8 & 18,3 & 13,5 & 0,6 & 0,3 & 16,5 & 72,0 & 11,5 & CL \\
\hline NÖ4 & 14,0 & 27,5 & 30,0 & 18,0 & 12,0 & - & 1,3 & 16,5 & 72,0 & 11,5 & CL \\
\hline N5 & 30,2 & 28,1 & 36,2 & 18,3 & 17,9 & 0,6 & 0,3 & 19,0 & 71,0 & 10,0 & CL \\
\hline NÖ5 & 18,5 & 28,1 & 40,0 & 20,0 & 20,0 & - & 1,0 & 19,0 & 71,0 & 10,0 & CL \\
\hline N6 & 51,8 & 27,4 & 71,4 & 35,3 & 36,1 & 0,4 & 0,5 & 10,2 & 77,6 & 12,2 & MH \\
\hline N7 & 19,0 & 28,0 & 22,0 & 15,0 & 7,0 & 0,8 & 0,1 & 4,8 & 80,2 & 15,0 & CL-ML \\
\hline N8 & 34,6 & 26,7 & 48,0 & 22,0 & 26,0 & 0,4 & 0,5 & 9,3 & 75,8 & 14,9 & CL \\
\hline N9 & 35,8 & 27,7 & 54,5 & 23,0 & 31,5 & 0,4 & 0,5 & 1,0 & 74,0 & 25,0 & CH \\
\hline
\end{tabular}

$\mathrm{W}_{\mathrm{n}}$ : Su muhtevası, $\gamma_{\mathrm{s}}$ : Dane birim hacim ağırlığı, $\mathrm{W}_{\mathrm{L}}$ : Likit limit, $\mathrm{W}_{\mathrm{p}}$ : Plastik limit, $\mathrm{I}_{\mathrm{p}}$ : Plastisite indisi, $\mathrm{I}_{\mathrm{L}}$ : Likitlik indisi, $\mathrm{I}_{\mathrm{c}}$ : Kıvam indisi, NÖ: Örselenmemiş numune 
Çizelge 2. Bir boyutlu ve üç boyutlu konsolidasyon deney sayıları

\begin{tabular}{|c|c|c|c|c|}
\hline $\begin{array}{c}\text { Numune } \\
\text { Numaras1 }\end{array}$ & $\begin{array}{c}\text { Üç Boyutlu } \\
\text { Konsolidasyon } \\
\text { Deneyleri Sayıs1 }\end{array}$ & $\begin{array}{c}\text { Üç Boyutlu Alet } \\
\text { ile Ödometre } \\
\text { Deneyleri Say1s1 }\end{array}$ & $\begin{array}{c}\text { Standart } \\
\text { Ödometre } \\
\text { Deneyleri } \\
\text { Say1s1 }\end{array}$ & $\begin{array}{c}\text { Örselenmemiş Numune } \\
\text { ile Standart Ödometre } \\
\text { Deneyleri Say1s1 }\end{array}$ \\
\hline N1 & 12 & - & 19 & - \\
\hline N2 & 6 & 2 & 11 & - \\
\hline N3 & 10 & 8 & 22 & 4 \\
\hline N4 & 6 & 6 & 12 & - \\
\hline N5 & 10 & 10 & 20 & - \\
\hline N6 & 8 & 8 & 16 & - \\
\hline N7 & 7 & 7 & 14 & - \\
\hline N8 & 6 & 5 & 11 & 10 \\
\hline N9 & 5 & 5 & & - \\
\hline
\end{tabular}

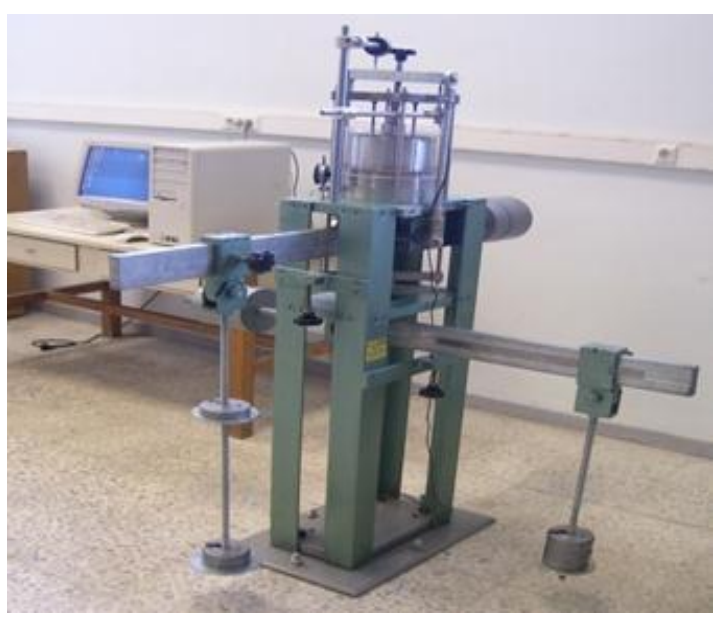

Şekil 1. Üç boyutlu konsolidasyon deney aleti

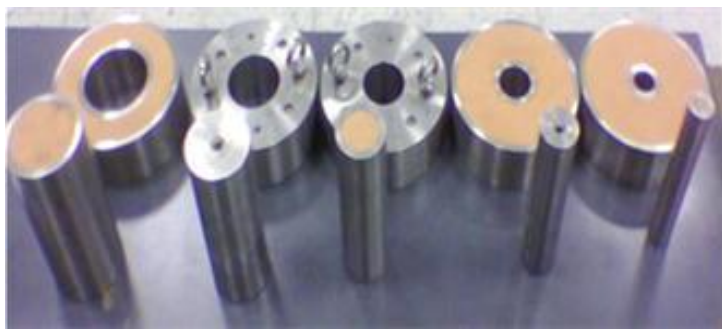

Şekil 2. Üst başliklar ve 20, 30, 40, 50, $60 \mathrm{~mm}$ çapında pistonlar
Numune bu gerilme etkisinde 24 saat konsolide edildikten sonra merkez bölgeye standart gerilme artımı uygulanmıştır (Şekil 3). Her ilave gerilme artımı esnasında standart zaman aralıklarında hem merkez bölgede hem de çevre bölgede standart zaman aralıklarında oturmalar kaydedilmektedir. Çevre bölgede simetrik iki noktada ölçüm yapılmaktadır. Üç boyutlu konsolidasyon deneylerinde $50 \mathrm{~mm}$ çapındaki merkez bölgeye standart ilave gerilme artımı uygulanırken bu bölgenin etrafinda $100 \mathrm{kPa}$ gerilme etkisinde bulunan zemin bulunmaktadır. Dolayısıyla $50 \mathrm{~mm}$ çapındaki merkez bölgenin yanal yönde şekil değiştirmesi tamamen engellenmemektedir. $\mathrm{Bu}$ nedenle üç boyutlu konsolidasyon deneyi olarak isimlendirilmektedir. Bilindiği üzere ödometre deneylerinde $50 \mathrm{~mm}$ çapındaki numunenin etrafinda bulunan ring yanal deformasyonu engellemektedir. Ödometre ve üç boyutlu konsolidasyon deneyleri esnasinda numunelere uygulanan eksenel gerilme durumu sirasiyla Şekil 3a ve Şekil 3b'de gösterilmiştir. Üç boyutlu deneylerde $120 \mathrm{~mm}$ çapındaki numunenin etrafında ring bulunmaktadır. Üç boyutlu deneylerin merkez bölge çapı ile ödometre deneylerinde kullanılan numune çap1 $(d=50 \mathrm{~mm})$ ve yüksekliği $(\mathrm{h}=20 \mathrm{~mm})$ aynıdır.

Numunelere uygulanan her gerilme 24 saat bekletilerek bu zaman sonundaki oturma miktarı konsolidasyon eğrilerinin çiziminde kullanılmıştır. 
Üc boyutlu konsolidasyon deney aleti hakkında detaylı bilgi Adıyaman [11], Baydoğan [12] ve Yıldırım [13] yayınlarında bulunmaktadır. Deney aletlerinin deney sonuçlarını etkileyebileceği düşüncesi ile ödometre deneyleri ayrıca üç boyutlu konsolidasyon deney aleti kullanılarak da yapılmıştır. Her iki deney sisteminde de numunelerin bulunduğu kap içerisinde su bulunmaktadır. Çalışmada eksenel yönde yer değiştirmeye izin verilmesi ve bu yönden ölçümlerin yapılması dolayısıyla ödometre deneyleri zaman zaman bir boyutlu olarak isimlendirilmektedir.

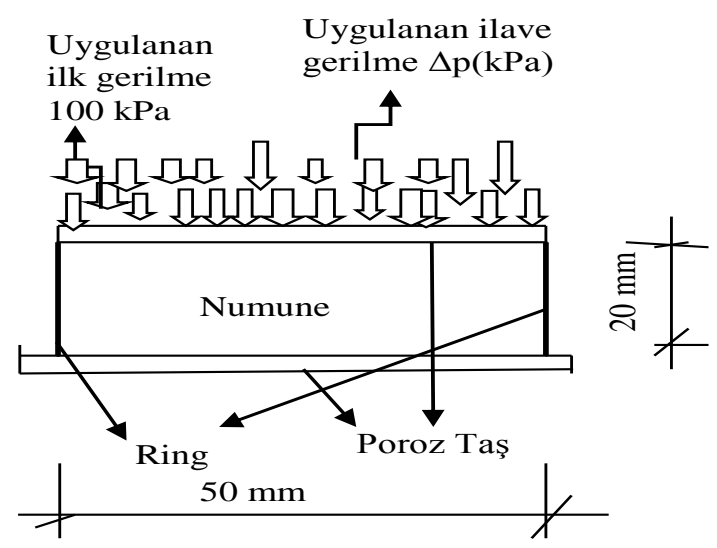

Şekil 3a. Ödometre deneylerinde eksenel gerilme durumu

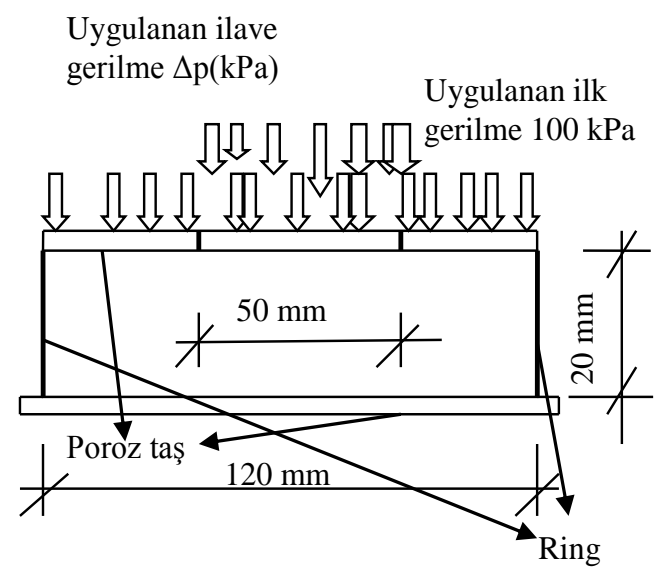

Şekil 3b. Üç boyutlu konsolidasyon deneylerinde gerilme durumu

\section{4. ÖN KONSOLIDDASYON BASINCI}

Konsolidasyon oturmasının arazi miktarlarına daha yakın hesaplanabilmesi, ön konsolidasyon basıncının yeterli doğrulukla belirlenmesine bağlıdır. Bilindiği üzere ön konsolidasyon basıncından daha büyük eksenel gerilme değerlerinde zemin yapısında ciddi değişiklikler meydana gelip, oturma miktarları artmaktadır. Örselenmemiş numunelerde numunelerin araziden alınmaları, alınma yöntemi (tüp, blok vb.), çevre koşullarından etkilenmemeleri için yalıtılmaları, laboratuarlara nakilleri, laboratuarlarda saklanmaları, laboratuar deneyleri için hazırlanmaları aşamalarında yeterli özen gösterilmesine rağmen bazı örselenmeler olmaktadır. $\mathrm{Bu}$ örselenmeler laboratuar deney sonuçlarına bağımlı çizilen oturma eğrilerini etkileyecektir. Oturma eğrilerinde örselenmelerin en etkili oldukları bölge ön konsolidasyon basıncına kadar olan bölümdedir. Dolayısıyla Casagrande yöntemi ile hesaplanan ön konsolidasyon basınc1 gerçek değerini vermeyecektir. Örselenmelerin oturma grafiklerini etkilediği durumlarda, deney sonuçları Ln(1+e)-Logaritma düşey gerilme eksenlerinde çizildiğinde, oturma eğrileri iki doğrudan oluşmaktadır. Çalışmada ödometre deney aleti ile yapılan deney sonuçları bu yönteme göre Şekil 4'de çizilmiştir. Grafiklerde görülen eğriler ilgili numune ile yapılan deneylerin ortalamasıdır.

Şekil 4'den görüldüğü üzere her numunenin oturma eğrisi $\operatorname{Ln}(1+\mathrm{e})$-Logaritma düşey gerilme eksenlerinde iki doğrudur. İki doğrunun kesim noktasındaki eksenel basınç değeri ön konsolidasyon basıncı olarak tanımlanmaktadır. Şekil 4'de net görülmemesine karşın her numunenin oturma eğrisi ilgili eksenlerde ayr1 biçimde çizildiğinde ön konsolidasyon basınçları bu yönteme göre, numunelerin gruplarına bağlı olarak $\quad 125 \sim 150 \quad \mathrm{kPa}$ basınç aralığında bulunmuştur. Benzer biçimde her numunenin bu yönteme dayalı ön konsolidasyon basıncı değerleri belirlenerek Çizelge 3'de gösterilmiştir.

Daha önceden söz edildiği üzere deney aletlerinin deney sonuçlarını etkileyebileceği düşüncesi ile 
ödometre deneyleri üç boyutlu konsolidasyon deney aleti kullanılarak da yapılmıştır. Bu deney sonuçları da aynı yöntem kullanılarak değerlendirildiğinde bulunan sonuçlar çizelge 3'de görülebilmektedir. Bu deney grubu sonucunda da ön konsolidasyon basınçları çizelge 3'den görüldüğü üzere yine $125 \sim 150 \quad \mathrm{kPa}$ olarak bulunmuştur. Yöntemin kullanımına örnek ve çizimlerin daha net görülebilmesi amacı ile örselenmemiş örnekleri ile de ödometre deneyleri yapılan N4 ve N5 deney sonuçlarında ön konsolidasyon basincinın bulunması sirasıyla Şekil 5 ve Şekil 6'da gösterilmiştir. Oturma eğrilerinin yaklaşık iki doğrudan oluştuğu Şekil 5 ve Şekil 6'da görülmektedir. İlgili şekillerden görüldüğü üzere yeniden konsolide edilerek hazırlanan numunelerde yaklaşık aynı değer ön konsolidasyon basıncı olarak bulunurken, örselenmemiş numunelerde daha büyüktür.

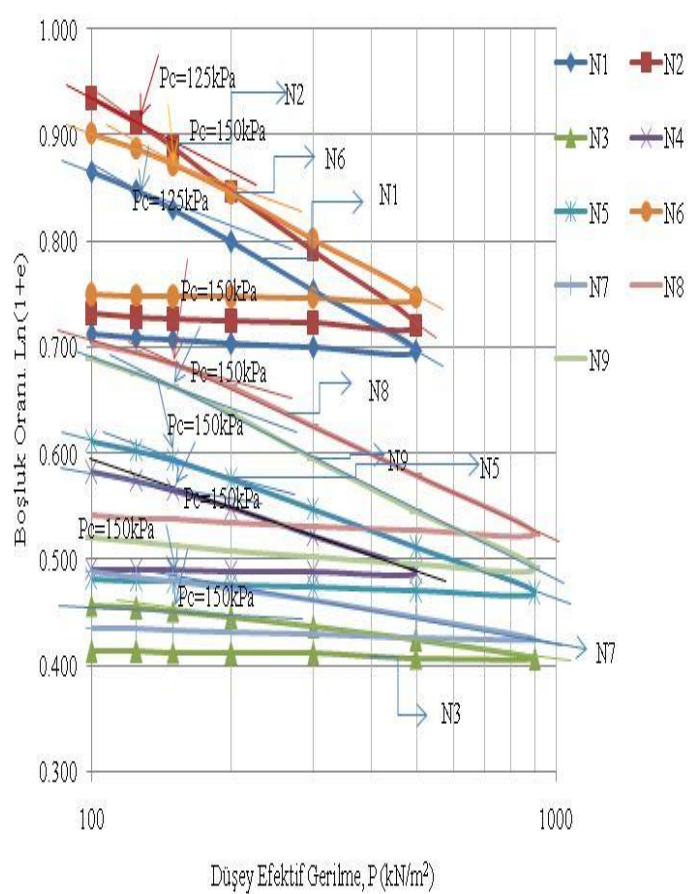

Şekil 4. Ln(1+e)-Log. eksenel gerilme yöntemi ile ön konsolidasyon basıncı

Çalışmada ayrıca üç boyutlu konsolidasyon deney aleti kullanılarak yapılan bir boyutlu ve üç boyutlu konsolidasyon deneyi sonuçlarında Casagrande yöntemi ile ön konsolidasyon basınçları bulunarak deney yönteminin ön konsolidasyon basincına etkisi araştırılmıştır. Casagrande yöntemi kullanılarak ödometre deneylerinde ön konsolidasyon basınçları numune grubuna bağımlı $130 \sim 180 \mathrm{kPa}$ aralığında bulunurken, aynı yöntem ile üç boyutlu konsolidasyon deneylerinde $160 \sim 200 \mathrm{kPa}$ aralığında bulunmuştur. Her numunenin bu yönteme göre ön konsolidasyon basınçları yine çizelge 3 'de görülebilmektedir. Numune 2 ve numune 4 ile yapılan üç boyutlu konsolidasyon deneyi merkez bölge değerlerinde Casagrande yöntemi ile ön konsolidasyon basıncının bulunması, yöntemin uygulanmasına örnek olması amacı ile Şekil 7 ve Şekil 8'de gösterilmiştir. Şekil 7'den görüldüğü üzere ön konsolidasyon basıncı bu yöntem ile üç boyutlu konsolidasyon deneyi merkez bölge sonuçlarında $165 \mathrm{kPa}$ bulunurken, aynı yöntem ile ödometre deney sonuçlarında $135 \mathrm{kPa}$ olarak bulunmuştur. Aynı numunenin ön konsolidasyon basinc1 ödometre deney sonuçlarında, Ln(1+e)-Logaritma düşey gerilme yöntemine göre Çizelge 3'den görüldüğü üzere $125 \mathrm{kPa}$ dır.

Şekil 7 ve Şekil 8'de bilindiği üzere, Po; olma olasılığı en büyük değer Pc; Casagrande yöntemine göre ön konsolidasyon basınc1, Pmax; ön konsolidasyon basıncının olabileceği en büyük sınır değerdir. Diğer numunelerin bu yönteme dayalı ön konsolidasyon basınçları benzer biçimde yine çizelge 3 'te görülebilmektedir.

Numune 4'ün üç boyutlu deney sonuçlarından ön konsolidasyon basıncı Şekil 8'den görüldüğü üzere Casagrande yöntemine göre $170 \mathrm{kPa}$ olarak bulunmuştur. Oysa bir boyutlu deney sonuçlarından aynı yönteme göre çizelge 3 'den görüldüğü üzere ön konsolidasyon basınc1 $150 \mathrm{kPa}$ olarak daha küçüktür.

Ön konsolidasyon basıncının belirlenmesinde kullanılan diğer bir yöntem, sıkışma modülüne $\left(\mathrm{Mc}=1 / \mathrm{m}_{\mathrm{v}}\right)$ karşılık, logaritma düşey efektif gerilme eksenlerinde deney sonuçlarının değerlendirilmesidir. Çizilen grafikte en küçük modül değerine karşılık gelen gerilme değeri ön 


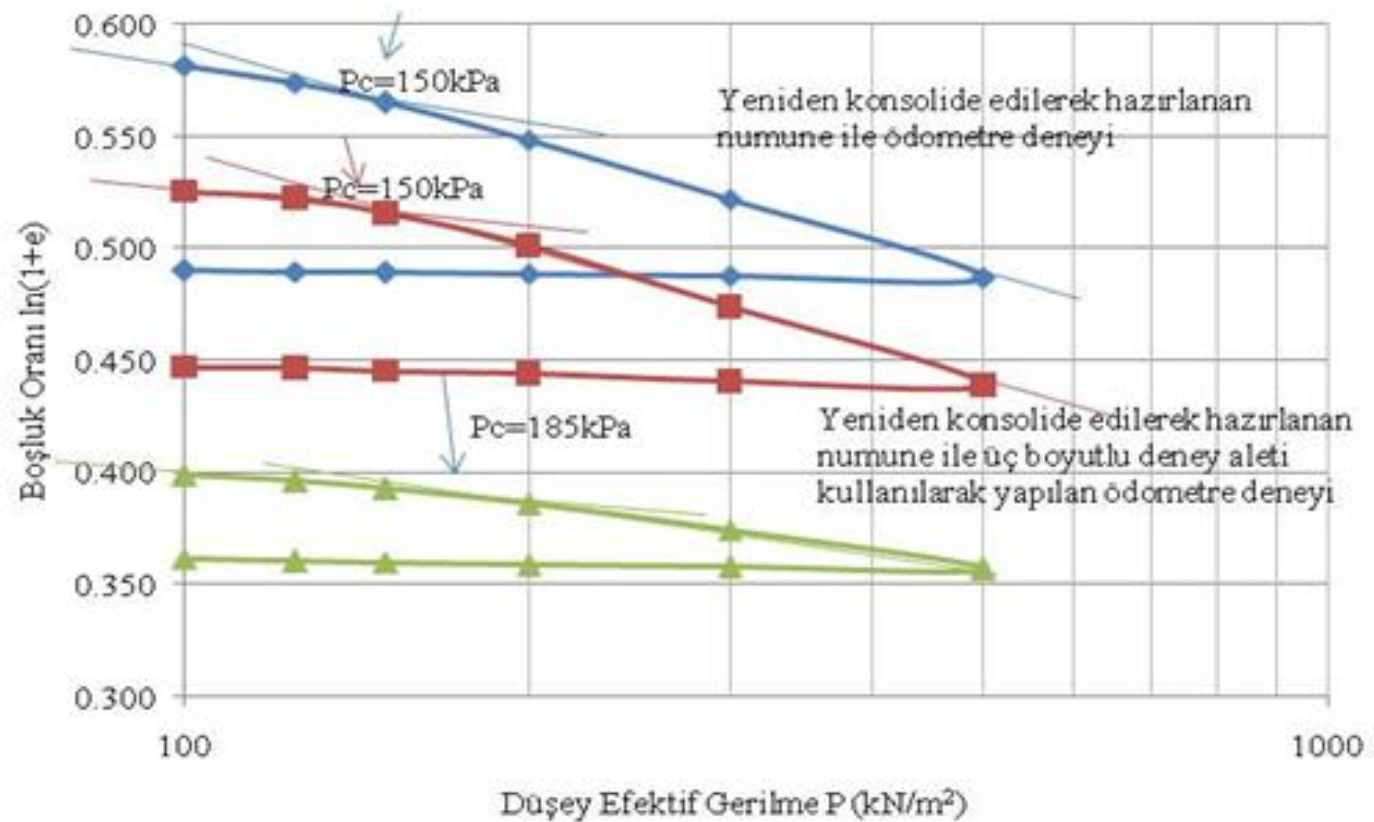

Şekil 5. Ln(1+e)-Log eksenel gerilme yöntemi ile ön konsolidasyon basınc1, N4(CL)

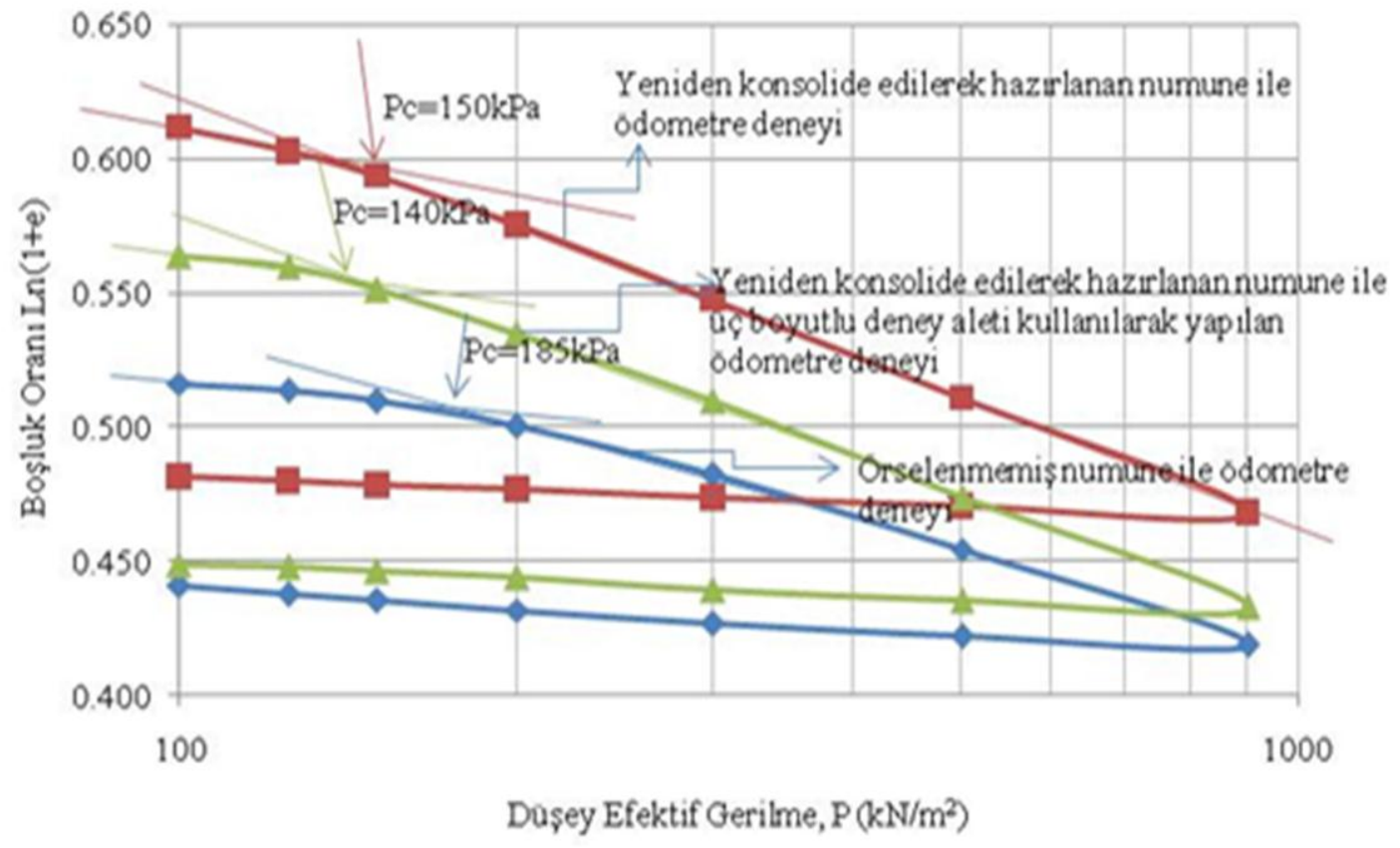

Şekil 6. Ln(1+e)-Log. eksenel gerilme yöntemi ile ön konsolidasyon basınc1, N5(CL) 


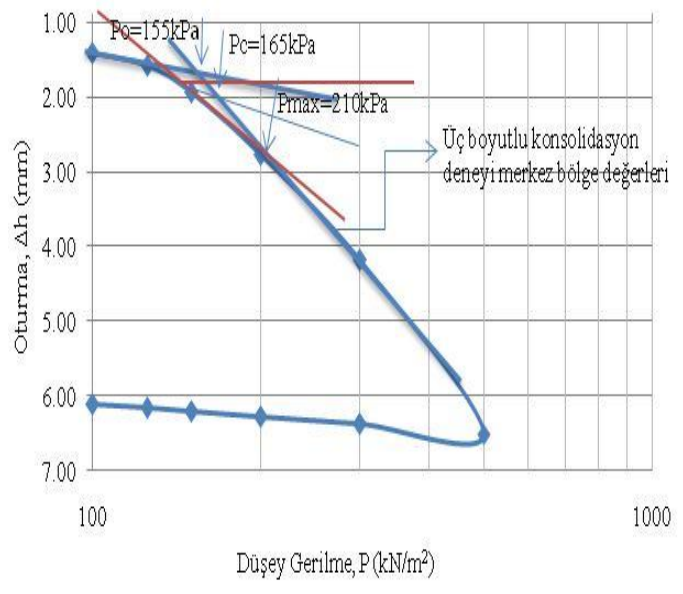

Şekil 7. Casagrande yöntemi ile ön konsolidasyon basinc1, N2(CH)

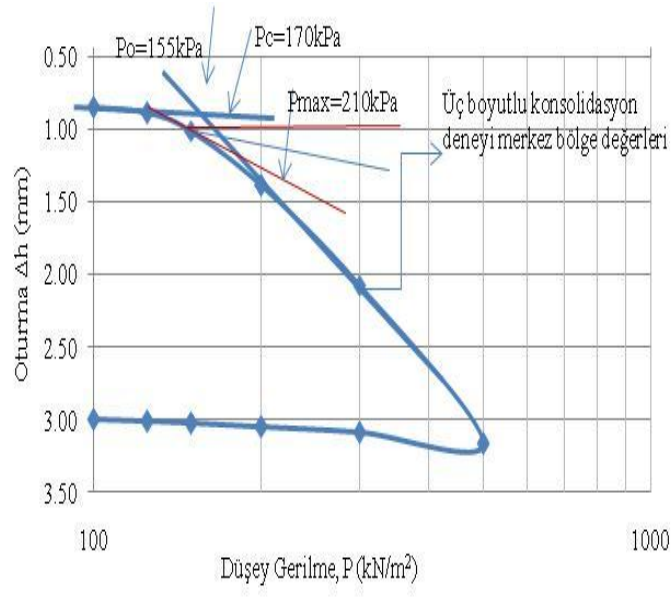

Şekil 8. Casagrande yöntemi ile ön konsolidasyon basinc1, N4(CL)

konsolidasyon basıncı olarak dikkate alınmaktadır. Çalışmada farklı hesap yöntemlerinin ön konsolidasyon basıncına etkisinin araştırılması amacı ile hem bir boyutlu deney sonuçları hem de üç boyutlu deney sonuçları bu yönteme göre değerlendirilmiştir. Yöntemin kullanımına örnek olması dolayısıyla N5 ve N6 deney sonuçlarının ilgili yönteme göre çizimi Şekil 9 ve Şekil 10'da sırasıyla gösterilmiştir. Diğer numunelerin bu yönteme göre ön konsolidasyon basıç̧ları Çizelge 4'de özetlenmiştir. Şekil 9'dan görüldüğü üzere 4 deney grubundan Sıkışma modülüLogaritma düşey gerilme yöntemi ile ön konsolidasyon basıçcları, $\operatorname{Ln}(1+\mathrm{e})$-Logaritma düşey gerilme ve Casagrande yöntemleri kullanılarak bulunan değerlerinden daha büyüktür.

Sıkışma modülü-logaritma eksenel gerilme yönteminde gerilme ekseninin logaritmik çiziminin uygun olmadığı Janbu ve Senneset [14], Germaine [15] yayınlarında önerilmektedir. Aritmetik eksenlerde deney sonuçları çizildiğinde ön konsolidasyon basıncı gerilme aralığ tanımlanmakta ve diğer yöntemler kullanılarak bulunan ön konsolidasyon basınçları ilgili aralıkta bulunmaktadır [15]. Tanımlanan biçimde çizilen grafikte sıkışma modülünde önemli azalma görüldükten sonra sıkışma modülü kabaca sabit değer almakta ve daha sonra eksenel gerilme ile lineer artım göstermektedir.

Şekil 10 yardımı ile numune 6 için de Sıkışma modülü-Logaritma düşey gerilme yöntemine dayalı ön konsolidasyon basınçları, diğer iki yöntem ile bulunan değerlerinden, Çizelge 3 ve Çizelge 4'den görüldüğü üzere genel olarak daha büyüktür. Gerilme ekseni logaritmik olduğunda da sıkışma modülün de önemli azalma görüldükten sonra, sıkışma modülünün kabaca sabit değer aldığı ve daha sonra gerilme ile lineer artım gösterdiği bölgeler Şekil 9 ve Şekil 10'da da görülebilmektedir. Üç boyutlu konsolidasyon deneyi merkez bölge grafiğinde ilgili gerilme aralığı Şekil 10'dan görüldüğü üzere 150 300 kPa'dır. Sıkışma modülü-Logaritma eksenel gerilme yöntemi ile yine Şekil 10'dan görüldüğü üzere aynı deney grubunda ön konsolidasyon basınc1 $220 \mathrm{kPa}$ bulunmuştur. Bulunan değerin tanımlanan gerilme aralığında kaldığ 1 yine Şekil 10'da görülmektedir. Numune 8 deney sonuçları sıkışma modülü-eksenel gerilme eksenlerinde Şekil 11'de çizilerek ön konsolidasyon basincı gerilme aralıkları gösterilmiştir. Gerilme ekseninin aritmetik olmas1 tanımlanan gerilme aralığını Şekil 9, 10, 11 yardımı ile önemli biçimde etkilememektedir. Numune 8 ile yapılan standart ödometre deney sonuçlarında $\operatorname{Ln}(1+\mathrm{e})$-Logaritma eksenel gerilme yöntemi ile ön konsolidasyon basincı 
Çizelge 3. Farklı yöntemlere göre ön konsolidasyon basınçları

\begin{tabular}{|c|c|c|c|c|}
\hline $\begin{array}{l}\text { Deney } \\
\text { Yöntemi }\end{array}$ & $\begin{array}{c}\text { Standart Deney } \\
\text { Aleti ile Ödometre }\end{array}$ & $\begin{array}{c}\text { Üç Boyutlu Deney } \\
\text { Aleti } \\
\text { ile Ödometre }\end{array}$ & $\begin{array}{l}\text { Üç Boyutlu Alet } \\
\text { ile Ödometre }\end{array}$ & $\begin{array}{c}\text { Üç Boyutlu Merkez } \\
\text { Bölge }\end{array}$ \\
\hline $\begin{array}{l}\text { Hesap } \\
\text { Yöntemi }\end{array}$ & $\begin{array}{c}\text { Ln(1+e)- } \\
\text { Logaritma Düşey } \\
\text { Gerilme }\end{array}$ & $\begin{array}{l}\text { Ln(1+e)-Logaritma } \\
\text { Düşey Gerilme }\end{array}$ & $\begin{array}{l}\text { Casagrande } \\
\text { Yöntemi }\end{array}$ & Casagrande Yöntemi \\
\hline $\begin{array}{l}\text { Numune } \\
\text { Numaras1 }\end{array}$ & $\begin{array}{c}\text { Ön Konsolidasyon } \\
\text { Basinc1 } \\
\left(\mathrm{kN} / \mathrm{m}^{2}\right)\end{array}$ & $\begin{array}{c}\text { Ön Konsolidasyon } \\
\text { Basınc1 } \\
\left(\mathrm{kN} / \mathrm{m}^{2}\right)\end{array}$ & $\begin{array}{c}\text { Ön } \\
\text { Konsolidasyon } \\
\text { Basinc1 } \\
\left(\mathrm{kN} / \mathrm{m}^{2}\right)\end{array}$ & $\begin{array}{c}\text { Ön Konsolidasyon } \\
\text { Basinc1. } \\
\left(\mathrm{kN} / \mathrm{m}^{2}\right)\end{array}$ \\
\hline N1 & 125 & - & - & 160 \\
\hline N2 & 125 & 125 & 135 & 165 \\
\hline N3 & 150 & 150 & 180 & 200 \\
\hline N4 & 150 & 150 & 150 & 170 \\
\hline NÖ4 & 185 & - & $155^{*}$ & - \\
\hline N5 & 150 & 140 & 150 & 160 \\
\hline NÖ5 & 185 & - & $170^{*}$ & - \\
\hline N6 & 150 & 140 & 130 & 160 \\
\hline N7 & 150 & 150 & 180 & 190 \\
\hline N8 & 150 & 160 & 145 & 190 \\
\hline N9 & 150 & 150 & 140 & 170 \\
\hline
\end{tabular}

*: Standart deney aleti ile yapılan deney sonucunda Casagrande yöntemi ile ön konsolidasyon basinc1

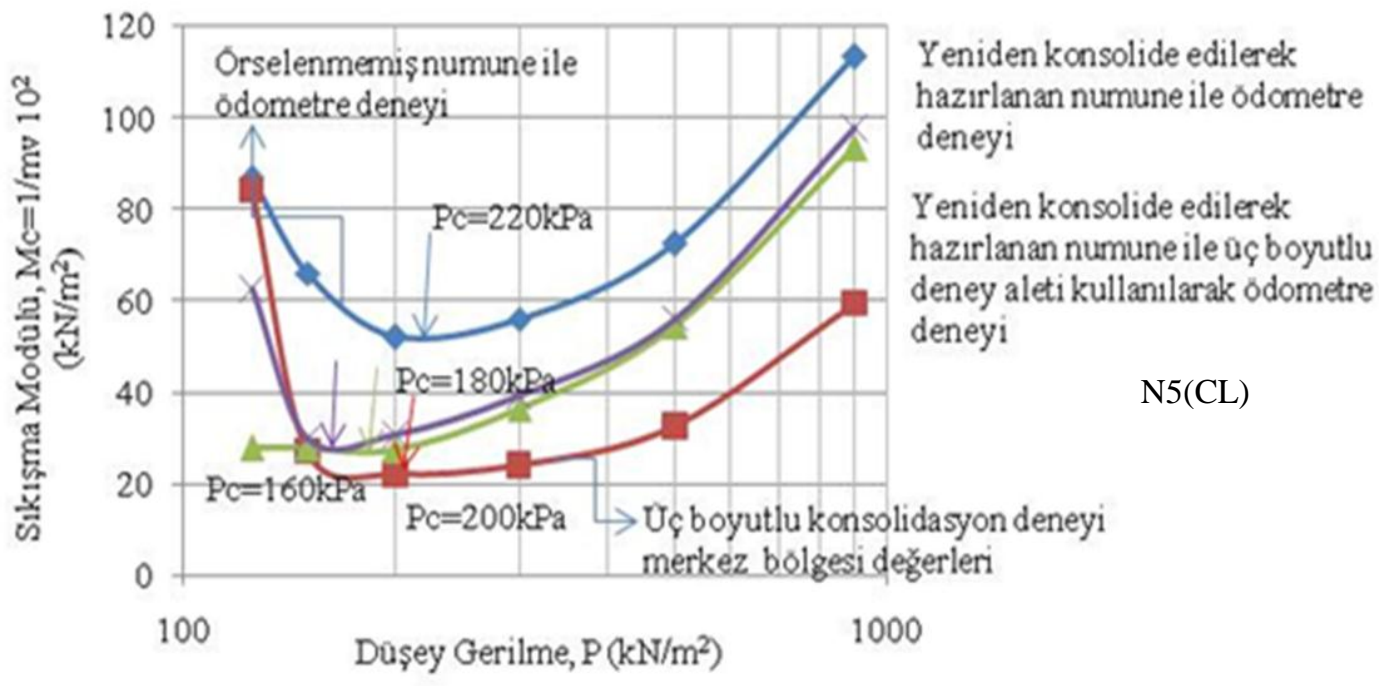

Şekil 9. Sıkışma modülü-Log. eksenel gerilme yöntemi ile ön konsolidasyon basıncı 


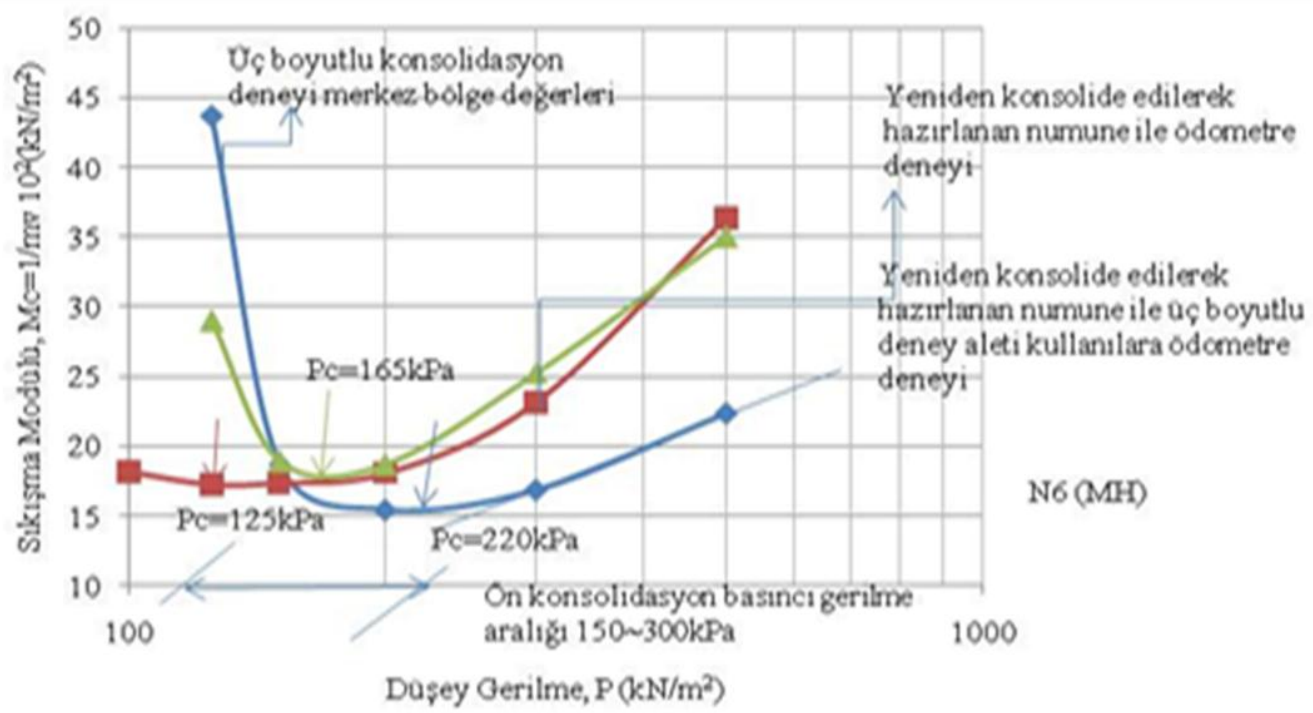

Şekil 10. Sıkışma modülü-Logaritma düşey gerilme yöntemi ile ön konsolidasyon basıncı

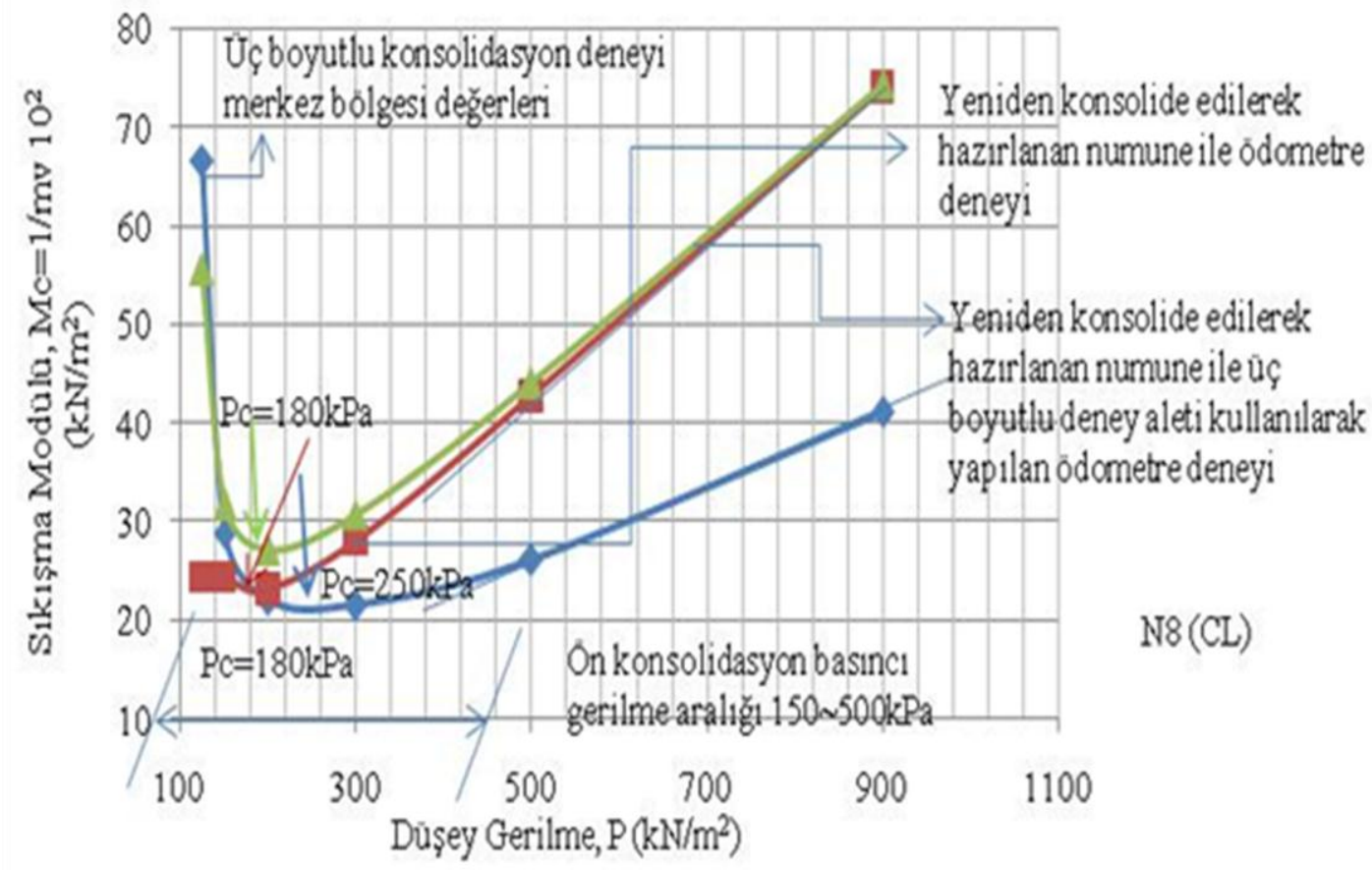

Şekil 11. Sıkışma modülü-Eksenel gerilme yöntemi ile ön konsolidasyon basıncı 
Çizelge 4. Sıkışma modülü-Logaritma düşey gerilme yöntemi ile ön konsolidasyon basınçları

\begin{tabular}{|c|c|c|c|c|}
\hline $\begin{array}{c}\text { Deney } \\
\text { Yöntemi }\end{array}$ & $\begin{array}{c}\text { Ödometre } \\
\text { Standart Deney } \\
\text { Aleti }\end{array}$ & $\begin{array}{c}\text { Ödometre Üç } \\
\text { Boyutlu Deney } \\
\text { Aleti }\end{array}$ & $\begin{array}{c}\text { Üç Boyutlu } \\
\text { Deneyler Merkez } \\
\text { Bölge }\end{array}$ & $\begin{array}{c}\text { Örselenmemiş } \\
\text { Numune }\end{array}$ \\
\hline $\begin{array}{c}\text { Numune } \\
\text { Numaras1 }\end{array}$ & $\begin{array}{c}\text { Ön } \\
\text { Konsolidasyon } \\
\text { Basinc1 }\end{array}$ & $\begin{array}{c}\text { Konsolidasyon } \\
\text { Basinc1 }\end{array}$ & $\begin{array}{c}\text { Ön } \\
\text { Konsolidasyon } \\
\text { Basınc1 }\end{array}$ & $\begin{array}{c}\text { Ön } \\
\text { Konsolidasyon } \\
\text { Basınc1 }\end{array}$ \\
\hline- & $\left(\mathrm{kN} / \mathrm{m}^{2}\right)$ & $\left(\mathrm{kN} / \mathrm{m}^{2}\right)$ & $\left(\mathrm{kN} / \mathrm{m}^{2}\right)$ & $\left(\mathrm{kN} / \mathrm{m}^{2}\right)$ \\
\hline N1 & 140 & - & 230 & - \\
\hline N2 & 130 & 180 & 210 & - \\
\hline N3 & 180 & 160 & 250 & 220 \\
\hline N5 & 150 & 165 & 200 & - \\
\hline N6 & 180 & 160 & 220 & - \\
\hline N7 & 125 & 165 & 280 & - \\
\hline N8 & 180 & 160 & 240 & - \\
\hline
\end{tabular}

Çizelge 3'den görüldüğg̈ üzere $150 \mathrm{kPa}$ olarak bulunmuştur. $\mathrm{Bu}$ değer Şekil 11'de ödometre deney sonuçları için tanımlanan aralık ile uyumludur. Aynı numunede sıkışma modülüLogaritma eksenel gerilme yöntemine göre standart ödometre deney sonuçlarında ön konsolidasyon basıncı Çizelge 4'ten görüldüğü üzere $180 \mathrm{kPa}$ olarak Şekil 11 'de tanımlanan aralıkta bulunmaktadır. Benzer biçimde diğer deney sonuçlarında da bu karşılaştırma yapıldığında diğer yöntemler ile bulunan ön konsolidasyon basınçlarının tanımlanan aralıklarla uyumlu olduğu görülmüştür. Diğer numunelerin sıkışma modülü-eksenel gerilme yöntemine göre gerilme aralıkları burada verilmemiştir.

Çizelge 3'den görüldüğü üzere düşük plastisiteli kil olan numune 8 'de $\operatorname{Ln}(1+\mathrm{e})$-Logaritma düşey gerilme yöntemine göre bir boyutlu konsolidasyon deneylerinden ön konsolidasyon basınc1 $150 \mathrm{kPa}$ olarak bulunurken, Casagrande yöntemine göre üç boyutlu konsolidasyon deneyi sonuçlarından 190 kPaolarak daha büyük bulunmuştur. Oysa Şekil 11'de ve Şekil 4'te Sıkışma modülüLogaritma düşey gerilme yöntemine göre ilgili değerler bir boyutlu deney Yukarıda çizilen eğrilere benzer biçimde diğer numunelerin bir ve üç boyutlu deney sonuçlarında da ön konsolidasyon basınçları Sıkışma modülüLogaritma düşey gerilme yöntemi ile bulunarak, ilgili değerler çizelge 4'de gösterilmiştir.

Nash vd. [5] yayınında da standart gerilme artımının uygulandığı (IL) deney sonuçlarından Sıkışma modülü-Logaritma düşey gerilme yöntemi ile bulunan ön konsolidasyon basınçları, Casagrande ve $\operatorname{Ln}(1+e)$-Logaritma düşey gerilme yöntemleri ile bulunan değerlerinden daha büyük olarak bulunmuştur.

Numunelerin gruplarına ve hesaplama yöntemlerine göre belirli aralıklarda tanımlanan ön konsolidasyon basınçları deneylerin yeterli sayılarda tekrar edilmesi ile bulunmuştur. Bazı numuneler çamur konsolidasyon aletinde iki defa hazırlanmıştır. Bazı numuneler çamur konsolidasyon aletinde yaklaşık bir y1l süre ile konsolide edilmiștir. Ön konsolidasyon basıncı olarak farklı yöntemler ile, numune sonuçlarında $180 \mathrm{kPa}$ ve üç boyutlu deney sonuçlarında $250 \mathrm{kPa}$ olarak diğer iki yöntemle belirlenen değerlerinden daha büyüktür. Çizelge 3 yardımı ile yüksek plastisiteli kil olan numune 9'da üç boyutlu konsolidasyon deneyi merkez bölge sonuçlarında ön konsolidasyon basıncı Casagrande 
yöntemine göre $170 \mathrm{kPa}$ olarak bulunurken, Çizelge 4'den görüldüğü üzere aynı grup deney sonuçlarında ilgili değer $240 \mathrm{kPa}$ olarak daha büyük bulunmuştur.

Yukarıda çizilen eğrilere benzer biçimde diğer numunelerin bir ve üç boyutlu deney sonuçlarında da ön konsolidasyon basınçları Sıkışma modülüLogaritma düşey gerilme yöntemi ile bulunarak, ilgili değerler çizelge 4'de gösterilmiştir.

Nash vd. [5] yayınında da standart gerilme artımının uygulandığı (IL) deney sonuçlarından Sıkışma modülü-Logaritma düşey gerilme yöntemi ile bulunan ön konsolidasyon basınçları, Casagrande ve $\operatorname{Ln}(1+\mathrm{e})$-Logaritma düşey gerilme yöntemleri ile bulunan değerlerinden daha büyük olarak bulunmuştur.

Numunelerin gruplarına ve hesaplama yöntemlerine göre belirli aralıklarda tanımlanan ön konsolidasyon basınçları deneylerin yeterli sayılarda tekrar edilmesi ile bulunmuştur. Bazı numuneler çamur konsolidasyon aletinde iki defa hazırlanmıştır. Bazı numuneler çamur konsolidasyon aletinde yaklaşık bir y1l süre ile konsolide edilmiştir. Ön konsolidasyon basıncı olarak farklı yöntemler ile, numune hazırlamakta kullanılan $125 \mathrm{kPa}$ eksenel basıncın bulunmaması, numunelerin arazide sahip oldukları özelliklerinin bir miktarını muhafaza etmelerinden kaynaklandığına inanılmaktadır. Numuneler etüvde $105^{\circ} \mathrm{C}$ kurutulup, danelerine ayrılıp tekrar belirli eksenel basınçta konsolide edildiklerinde sahip oldukları özelliklerin tamamını kaybetmemektedirler. Literatürde eksenel ilave gerilme uygulanması durumunda daneler arası boşlukların araştırıldığı çalışmalarda benzer açıklama bulunmaktadır.

Çizelge 3 ve Çizelge 4 yardımı ile 9 farklı plastisite indisli, yeniden konsolide edilerek hazırlanan numuneler ve 2 örselenmemiş numune ile yapılan bir boyutlu ve üç boyutlu konsolidasyon deneyi sonuçlarından genel olarak; standart ödometre deneylerinden, $\mathrm{Ln}(1+\mathrm{e})$-Logaritma düşey gerilme yöntemine göre ön konsolidasyon basınçları, $125 \mathrm{kPa} \sim 150 \mathrm{kPa}$ olarak diğer iki yöntem ile bulunan değerlerinden daha küçük olarak bulunmuştur. Bu grup deney sonuçlarında Sıkışma modülü-Logaritma düşey gerilme yöntemine dayalı ön konsolidasyon basınçları $125 \mathrm{kPa} 180 \mathrm{kPa}$ olarak hesaplanmıştır. Yine bu yönteme göre üç boyutlu deney aleti ile yapılan ödometre deneyi sonuçlarında ilgili değerler $\quad 160 \quad \mathrm{kPa} \sim 180 \quad \mathrm{kPa}$ olarak $\operatorname{Ln}(1+e)$-Logaritma düşey gerilme yönteminden bulunan $125 \mathrm{kPa} \sim 160 \mathrm{kPa}$ değerlerinden daha büyüktür. Casagrande yöntemi ile ön konsolidasyon basınçları ödometre deneyi sonuçlarında $130 \quad \mathrm{kPa} \sim 180 \quad \mathrm{kPa}$ olarak, Ln(1+e)-Logaritma düşey gerilme yönteminden daha büyük hesaplanırken sıkışma modülü-Logaritma düşey gerilme yöntemi ile bulunan değerlerinden daha küçüktür.

Üç boyutlu konsolidasyon deneyi merkez bölge sonuçlarında da ödometre deneyi sonuçlarına benzer biçimde ön konsolidasyon basınçları S1kışma modülü-Logaritma düşey gerilme yöntemi ile $200 \mathrm{kPa} 280 \mathrm{kPa}$ olarak, Casagrande yöntemi ile hesaplanan $160 \mathrm{kPa} \sim 200 \mathrm{kPa}$ değerlerinden daha büyüktür.

Deneysel çalışma sonuçlarından en küçük ön konsolidasyon basınçları $\operatorname{Ln}(1+\mathrm{e})$-Logaritma düşey gerilme yönteminden bulunurken, bu değeri Casagrande yöntemi ile bulunan değerler izlemektedir. En büyük değerler ise sıkışma modülü-Logaritma düşey gerilme yönteminden hesaplanmıştır. Örselenmemiş numunelerden bulunan ön konsolidasyon basınçlarının aynı numunelerin yeniden hazırlanan örneklerinden bulunan değerlerinden genel olarak daha büyük olduğu yine ilgili şekillerden görülmektedir. Üç yönteme dayalı bulunan bütün değerlerin sıkışma modülü-eksenel gerilme aralığına uyumlu olduğu deneysel çalışma sonucundan gözlenmiştir. $\mathrm{Bu}$ açıklamalara bağımlı olarak ön konsolidasyon basıncinın, numunelerin tipine, numune alma yöntemlerine, deney yöntemlerine ve hesaplama yöntemlerine bağımlı olduğunu söyleyebiliriz.

\section{SONUÇLAR}

Yeniden konsolide edilerek hazırlanan numunelerin yanı sıra iki örselenmemiş numune ile de çalışmada bir boyutlu ve üç boyutlu 
konsolidasyon deneyleri yapılmıştır. Ön konsolidasyon basıncinın konsolidasyon oturmasının hesaplanmasında önemli olduğu bilinerek, Casagrande yönteminin yanı sıra diğer yöntemlerin kullanımları çalışmada gözden geçirilmiştir. Üç boyutlu ve ödometre deney aletleri kullanılarak yapılan bir boyutlu konsolidasyon deneyi sonuçları $\operatorname{Ln}(1+\mathrm{e})$, Logaritma düşey efektif gerilme eksenlerinde çizildiğinde oturma eğrilerinin yaklaşık iki doğrudan oluştuğu görülmüştür. İki doğrunun kesim noktasındaki eksenel gerilme değeri ön konsolidasyon basıncı olarak tanımlanmaktadır. Hem standart deney aleti hem de üç boyutlu deney aleti kullanılarak yapilan bir boyutlu konsolidasyon deneyi sonuçları Ln(1+e)-Logaritma düşey gerilme eksenlerinde çizildiğinde her iki grup deney sonucunda da ön konsolidasyon basıcçları numunelerin gruplarına bağlı olarak $125 \mathrm{kPa} \sim 150 \mathrm{kPa}$ gerilme aralığında bulunmuştur.

Deney yönteminin ön konsolidasyon basıncına etkisinin görülebilmesi düşüncesi ile üç boyutlu deney aleti kullanılarak yapılan bir boyutlu ve üç boyutlu konsolidasyon deneyi sonuçlarında Casagrande yöntemine göre ön konsolidasyon basınçları hesaplanmıştır. Bir boyutlu deney sonuçlarında Casagrande yöntemine göre ön konsolidasyon basınçları $130 \quad \mathrm{kPa} \sim 160 \quad \mathrm{kPa}$ arasında bulunurken, üç boyutlu konsolidasyon deneyi sonuçlarında $130 \mathrm{kPa} 200 \mathrm{kPa}$ olarak daha büyük değerler bulunmuştur.

Farklı hesap yöntemlerinin ön konsolidasyon basıncina etkisinin incelenmesi dolayısıyla Sıkışma modülü-Logaritma düşey gerilme yöntemine göre ön konsolidasyon basınçları hesaplanmıştır. İlgili yönteme göre ön konsolidasyon basıncı değerleri standart ödometre deney aleti ile yapılan bir boyutlu deneylerde 125 180 kPa olarak bulunurken, üç boyutlu deney aleti kullanılarak yapılan aynı grup deneylerde $160 \sim 180 \mathrm{kPa}$ aralığında bulunmuştur. En büyük ön konsolidasyon basıncı değerleri Sıkışma modülüLogaritma düşey gerilme yöntemine dayalı olarak üç boyutlu konsolidasyon deneylerinden $200 \sim 220 \mathrm{kPa}$ arasında bulunmuştur. Bu yönteme dayalı hesaplanan ön konsolidasyon basinc1 değerleri, genel olarak Ln(1+e)-Logaritma düşey gerilme ve Casagrande yöntemlerine göre hesaplanan ön konsolidasyon basıncı değerlerinden daha büyüktür. En küçük ön konsolidasyon basıncı değerleri Ln(1+e)-Logaritma düşey gerilme yönteminden bulunurken bu değerleri Casagrande yöntemi ile hesaplanan değerler izlemektedir.

Numune tipinin ön konsolidasyon basıncına etkisinin araştırılması amacı ile hem örselenmemiş hem de yeniden konsolide edilerek hazırlanan numunelerle yapılan bir boyutlu konsolidasyon deneyi sonuçlarında farklı yöntemler ile ön konsolidasyon basınçları hesaplanmıştır. Örselenmemiş numunelerden yeniden konsolide edilerek hazırlanan numunelere oranla genel olarak daha büyük değerler bulunmuştur.

Dolayısıyla gerilme artımının kullanıldığı bir ve üç boyutlu konsolidasyon deneyi sonuçlarına bağımlı olarak ön konsolidasyon basıncının, deneylerde kullanılan numunelerin tipine, konsolidasyon deney yöntemlerine ve ön konsolidasyon basıncının bulunmasında kullanılan yöntemlere bağlı olduğunu söyleyebiliriz.

\section{SEMBOLLER}

CRS sabit deformasyonun uygulandığı ödometre deneyi

CHG hidrolik eğimin kontrol edildiği ödometre deneyi

RF akımın engellendiği ödometre deneyi

IL standart gerilme artımı

E boşluk oranı

Mc sıkışma modülü

$\mathrm{m}_{\mathrm{v}} \quad$ hacimsel sıkışma sayısı

d numune çap1

h numune yüksekliğ $\mathrm{i}$

Wn su muhtevası

$\mathrm{W}_{\mathrm{L}} \quad$ likit limit

$\mathrm{Wp} \quad$ plastik limit

Ip plastisite indisi

$\mathrm{I}_{\mathrm{L}} \quad$ likitlik indisi

Ic kıvam indisi

$\gamma \mathrm{s} \quad$ dane birim hacim ağırlığı

MH yüksek plastisiteli silt

$\mathrm{CH} \quad$ yüksek plastisiteli kil

CL-ML düşük plastisiteli kil-silt 


$\begin{array}{ll}\mathrm{CL} & \text { düşük plastisiteli kil } \\ \mathrm{P} & \text { eksenel gerilme } \\ \mathrm{Pc} & \text { ön konsolidasyon basıncı } \\ \mathrm{Po} & \text { ön konsolidasyon basıncının olma } \\ & \begin{array}{l}\text { olasılı̆̆ının en büyük olduğu değer } \\ \text { Pmax konsolidasyon basıncının } \\ \end{array} \\ & \text { olabileceği en büyük sınır değer }\end{array}$

\section{KAYNAKLAR}

1. Brumund, W. F., Jonas, E., Ladd, C. C., 1976. Estimating in Situ Maximum Past Preconsolidation Pressure of Saturated Clays from Results of Laboratory Consolidometer Tests, Special Report 163, Transportation Research Board, 4-12.

2. Leonard, G. A., 1976. Estimating Consolidation Settlements of Shallow Foundations on over Consolidated Clays, Special Report 163, Transportation Research Board, 13-16.

3. Holtz, R. D., Kovacs, W. D., 1981. An Introduction to Geotechnical Engineering, Prentice-Hall, Inc., Englewood Cliff, N. J.

4. Sandbaeken, G., Berre, T., Lacasse, S., 1985. Oedometer Testing at the Norwegian Geotechnical Institude, ASTM Symposium on Consolidation Behaviour Of Soils, Ft. Lauderdale, Fla., also Internal Report, No. 56300-9, Norwegian Geotechnical Institute, Oslo, Norway.

5. Nash, D. F. T., Sills, G. C., Davison, L. R., 1992. One-Dimensional Consolidation Testing of Soft Clay from Bothkennar, Geotechnique 42, No 2, 241-256.

6. Holtz, R. D., Jamiolkowski, M. B., Lancellotta, R., 1986. Lessons from Oedometer Tests on High Quality Samples, Journal of Geotechnical Engineering, ASCE, Vol. 112, No 8, 768-776.

7. Butterfield, R., 1979. A Natural Compression Law for Soils (an advance on e-log p). Geotechnique 29, No 4, 469-480.

8. Onitsuka, K., Hong, Z., Hara. Y., Yoshitake, S., 1995. Interpretation of Oedometer Test Data for Natural Clays, Soils Foundation 35, No 3, 61-70.

9. Hong, Z. S., Yin, J., Cu1, Y. J., 2010. Compression Behaviour of Reconstituted Soils at High Initial Water Contents, Géotechnique 60, No 9, 691-700.
10. Janbu. N., 1969. The Resistance Concept Applied to Deformations of Soils, Proc. $7^{\text {th }}$ Int., Conf. Soil Mech., Mexico 1, 191-196.

11. Adiyaman, İ. B., 2005. Üç Boyutlu Konsolidasyon Deney Sistemi, Yüksek Lisans Tezi, İstanbul Teknik Üniversitesi, Fen Bilimleri Enstitüsü.

12. Baydoğan, H., 2007. Üç Boyutlu Konsolidasyon, Yüksek Lisans Tezi, İstanbul Teknik Üniversitesi, Fen Bilimleri Enstitüsü.

13. Yıldırım, H., Sezen, A., 2010. Yeni Geliştirilen Deney Aleti ile Laboratuarda Zemin Özelliklerinin Belirlenmesi, Tübitak, Araştırma Projesi.

14. Janbu, N., Senneset, K., 1979. Interpretation Procedures for Obtaining Soil Deformation Parameters, Proc. 7th ECSMFE, Brighton, Vol.1, 185-188.

15. Germaine, J. T., 1985 . Laboratory Measurements of Clay Behavior, M.I.T. Cambridge, MA .

16. Atkinson, J., 2007. The Mechanics of Soils and Foundations, $2^{\text {nd }}$ Edition, Taylor and Fransis, London and New York.

17. Craig, R. F., 1983. Soil Mechanics, $3^{\text {rd }}$ Edition, Van Nostrand Reinhold, UK.

18. Kumbasar, V., Kip, F., 1999. Zemin Mekaniği Problemleri, Çağlayan Kitabevi, İstanbul. 
